\title{
OPPORTUNITIES FOR IMPLEMENTATION OF INTERDISCIPLINARITY IN GEOGRAPHY EDUCATION
}

DOI: https://doi.org/10.18509/GBP210619m

DOI: 37.02:911(497.2)

7.043:911(497.2)

\author{
Stanislava Misheva \\ Sofia University "St. Kliment Ohridski”, Faculty of Geology and Geography, Department \\ "Regional development", Bulgaria
}

\begin{abstract}
Contemporary didactics of geography perceives interdisciplinarity as a basic regulatory principle of subject teaching. In principle, it is not new, but today it is perceived as particularly relevant, given its role in making interdisciplinary links in the learning process. Interdisciplinarity is associated with the integration of geographical and nongeographical issues in geography education. At the present stage, this is especially important, because the solution of more complex learning tasks requires to approach them not only through the eyes of a learning discipline. Regarding the curriculum in geography and economics, considered in the system of geographical education in our country, the question seems even more relevant. New curricula in geography and economics abound in such complex learning tasks that directly affect reality.

The integration of the subjects, as well as the joint work of the respective teachers, are of different intensity. Therefore, it is not surprising that there is an abundance of definitions and modifiers often used as synonyms for integration in education - cross-curricular learning, interdisciplinary learning, blended learning, integrative learning, multidisciplinary learning and more.

The present study is a modest attempt to interpret the interdisciplinarity between geography and history in the learning process. Of course, we would not claim completeness in one report. In this sense, we will highlight some issues that deserve further research, first: what are the possibilities for interdisciplinarity, and second: what are the possible problems associated with it.
\end{abstract}

Keywords: principles of teaching, interdisciplinarity, geography education, history education

\section{INTRODUCTION}

What is meant by interdisciplinarity?

The issue of interdisciplinarity is especially relevant in modern didactics. Evidence of this are the numerous interpretations on the issue and the realization that linking different subjects will lead to better results and higher quality of education in high school. [1], [8], [9]

In general, interdisciplinarity can be defined as the "coordinated interaction of two or more disciplines" and, more particularly, the interaction of their "teaching methodology", which seeks to give a global rather than a concrete vision of problems or topics related to different disciplines. " [3]

In order to define interdisciplinarity, it is necessary to first make a distinction from others, widely used in the literature, often as equivalent concepts (Table 1). 
Table 1. Distinguishing interdisciplinarity, [7]

\begin{tabular}{|l|l|l|}
\hline Multidisciplinarity & Interdisciplinarity & Transdisciplinarity \\
\hline $\begin{array}{l}\text { Comparison of different } \\
\text { disciplines, sometimes }\end{array}$ & $\begin{array}{l}\text { Interaction between two or more } \\
\text { disciplines: this interaction can range } \\
\text { without a visible } \\
\text { from simple communication of ideas } \\
\text { connection between } \\
\text { them. }\end{array}$ & $\begin{array}{l}\text { Application } \\
\text { axiomatics common to a } \\
\text { set of disciplines. } \\
\text { concepts, knowledge theory, } \\
\text { methodology, procedures, data and } \\
\text { organization of research and teaching. }\end{array}$ \\
\hline
\end{tabular}

The distinction in the table can be supplemented by other concepts:

- Interdisciplinarity is "cooperation between different disciplines or between different sectors of the same science to achieve real interactions, reciprocity of exchange, for mutual enrichment." [2]

- Interdisciplinarity "arises when different disciplines interact with a specific research objective and in a specific field of application". [7]

- In the context of school education, "in the specific didactic scenario, it is largely a matter of momentary manifestations of limited interdisciplinarity and the creation of relationships, usually oriented towards the achievement of specific goals" (ibid.).

- Interdisciplinarity is what is lacking in the discipline to embrace reality. It establishes bridges, emphasizes interactions, differences, analogies, suggests dialogue, listening, open vision. [5]

- In instrumental terms, "means... convergence of specific skills; in terms of learning content - learning, knowing and understanding reality..." [6]

It is clear from the definitions that the issue under consideration is not indisputable. However, it can be concluded that the common aspect between the disciplines stands out, aimed at explaining certain phenomena and approaching them from another point of view. This conclusion can be supplemented by Piaget's view that using an interdisciplinary approach we could look at an aspect in a more global way.

The complexity of the interdisciplinary connections is clearly visible. It is not enough for the disciplines to be simply comparable. They must be closely related to each other.

Where is the interdisciplinarity between geography and history?

The closeness between history and geography is indisputable. Its educational significance can be realized through clearly coordinated and integrated educational methodologies. This closeness is complex due to the fact that a person is both an inhabitant of time and an inhabitant of space:

„Hardly anyone will dispute the need to include the spatial dimension in the study of historical facts, as well as the temporal dimension in the consideration of geographical regions, topics and problems." [4]

The knowledge, skills and competencies for dealing with geographical and historical problems, which are activated and acquired in the learning process, emphasize the strong capacity of multidisciplinary synthesis and the methods of the considered disciplines. It is clear that the curriculum of each of the two subjects is not enough to separate them from each other - both disciplines deal with migration, agriculture and globalization. What distinguishes them is the research methodology and the reflections that accompany it. In this sense, a method must be sought to avoid the predominance of geography over history and vice versa. This also supports Piaget's view that in interdisciplinary work the two disciplines enrich each other. [2], [4] 
Proof of the closeness between geography and history is the emergence of "geohistory" and "historical geography". In order to avoid the strong dominance of one of the two disciplines, it is essential to distinguish ourselves from the two approaches mentioned above. In this regard, the training offers to address topics related to global issues from different perspectives, both in their temporal evolution and in their spatial perspective. In this way, students have the opportunity to develop their critical thinking, to compare and understand the complexity and interdependence of phenomena.

What is the methodological aspect of interdisciplinarity?

The interdisciplinary methodology is systematic. According to Joël De Rosnay, this allows knowledge to be organized in different ways and understood not only through analysis but also through synthesis. Therefore, systematic knowledge differs from analytical knowledge (Table 2).

Table 2. Analytical approach and systematic approach, [5]

\begin{tabular}{|l|l|}
\hline Analytical approach & Systematic approach \\
\hline $\begin{array}{l}\text { Isolation of the elements of the analyzed } \\
\text { system. It is based on the precision of the } \\
\text { details from a local point of view. }\end{array}$ & $\begin{array}{l}\text { You connect the interdependent elements of the } \\
\text { analyzed system from a global point of view. } \\
\text { Modifying only one variable. }\end{array}$ \\
$\begin{array}{l}\text { The analyzed system is closed and can be } \\
\text { divided into minimal units. }\end{array}$ & $\begin{array}{l}\text { The analyzed system is open and can be } \\
\text { divided into subsystems or modules in constant } \\
\text { interaction. } \\
\text { The system is independent of the duration. The } \\
\text { Thenections are simple and linear. }\end{array}$ \\
$\begin{array}{l}\text { The system is autonomous and incomplete. } \\
\text { and is part of a temporal and historical process. } \\
\text { Relationships are complex and have circular } \\
\text { causality. } \\
\text { The system is heteronomous, purposeful and } \\
\text { action-oriented. }\end{array}$ \\
\hline $\begin{array}{l}\text { Leads to teaching in comparable disciplines } \\
\text { (multidisciplinarity) }\end{array}$ & \begin{tabular}{l} 
This leads to interdisciplinary training \\
\hline
\end{tabular} \\
\hline
\end{tabular}

Interdisciplinarity is the concretization of the desire to integrate and consider a problem from another point of view. In this way the associative vision of the disciplines develops. [5]

The systematic approach, due to its wide distribution in the humanities, provides a sufficiently flexible and open methodological horizon. His fields of study, due to their large number, emphasize the interdependent relationships between the system as a whole.

Interdisciplinary activity in the learning process!

As mentioned earlier, in order to carry out interdisciplinary activity in the learning process, in the first place it is necessary for the disciplines to be strongly connected. Specific lessons should be well structured to make it as easy as possible for students to find specific information and connections between subjects.

An exemplary interdisciplinary activity between geography and history can be carried out on the topic "Bulgaria on the world map" (see Table 3). Another example of interdisciplinary activity at European level is the example of "Switzerland's political role" (see Table 4). 
Table 3. Proposal for interdisciplinary activity in geography and history Topic: Bulgaria on the world map Grade: 7 and/or 10 grade

\begin{tabular}{|c|c|c|}
\hline Stages & Goals, students... & Subject \\
\hline $\begin{array}{l}\text { Introduction: } \\
\text { structure of Bulgaria }\end{array}$ & $\begin{array}{l}\text { Determine the state structure of Bulgaria; The children } \\
\text { are able to connect the previously discussed information } \\
\text { (borders and geographical location of Bulgaria) with }\end{array}$ & Geography \\
\hline $\begin{array}{l}\text { Has Bulgaria always been } \\
\text { as we know it? }\end{array}$ & $\begin{array}{l}\text { what they have just discovered (state system) } \\
\text { The children make a hypothesis about what was the } \\
\text { development of Bulgaria in time; } \\
\text { Children are able to analyze a historical source to test } \\
\text { their hypothesis; } \\
\text { The children can present the borders when founding }\end{array}$ & History \\
\hline happening? & Bulgaria on a map (681); & History \\
\hline $\begin{array}{l}\text { Conclusion: how does the } \\
\text { country we live in work? }\end{array}$ & $\begin{array}{l}\text { The children are able to emphasize the main changes } \\
\text { that have taken place between the founding of the } \\
\text { country and the current situation } \\
\text { Children are able to detect these changes in time and } \\
\text { illustrate them in space; } \\
\text { The children know how the political system of Bulgaria } \\
\text { works and are able to explain it; } \\
\text { The children know when Bulgaria adopted this system }\end{array}$ & \\
\hline
\end{tabular}

Table 4. Proposal for interdisciplinary activity in geography and history Topic: Switzerland's political role. Class: $9,11,12$ grade

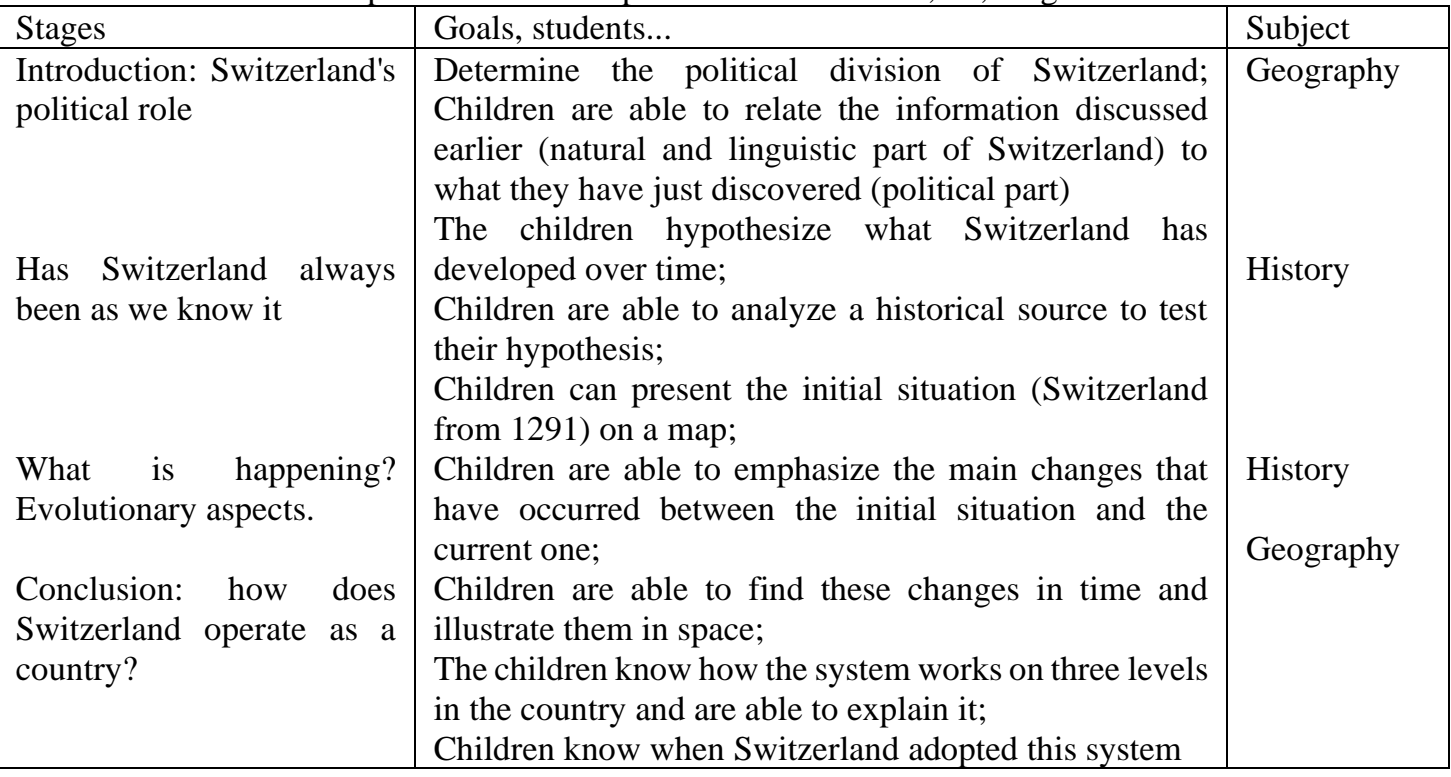

Where is the problem?

The problems that arise in the construction of interdisciplinary training in the disciplines of history and geography are directly related to the annual planning of educational activities. The comparison between the curricula in geography and economics and history and civilizations for high school in Bulgaria shows insufficient opportunities for comprehensive planning of interdisciplinary topics to be studied simultaneously by both disciplines and aimed at achieving the goals set in the curriculum. In history, for example, it is necessary to introduce an aspect that is placed several centuries later than what has been done so far. In some historical periods, it is necessary to go back in time to reconstruct key events, and the use of retrospection, according to some researchers, would make it difficult for some students. In order to avoid this problem, it is expedient to carry out interdisciplinary activity on specific topics of the curricula in both subjects and which 
have common ground with both disciplines. This will allow students to connect and analyze information more easily by performing short activities and using the concepts under consideration in a historical or geographical context. They can be used in the other area to highlight the links between the two subjects and to allow students to observe how some aspects relevant to one situation may be valid in others and therefore to gain a broader vision of the subject matter. In this case, there is more freedom in choosing the classes with which the activities can be performed, as they are shorter. In this way, cooperation between teachers is facilitated.

\section{CONCLUSION}

Interdisciplinarity is associated with the integration of geographical and non-geographical issues in geography education. At the present stage, this is especially important, because the solution of more complex learning tasks requires to approach them not only through the eyes of a discipline. New curricula in geography and economics abound in such complex learning tasks that directly affect reality.The connection between geography and history is indisputable. Despite the difficulties in the overall annual thematic planning, it is appropriate to search for specific interdisciplinary topics in the curricula of the two disciplines, aimed at achieving the goals of teaching geography and history in parallel.

\section{REFERENCES}

[1] Василева, М., Методика на обучението по география - едно по-широко разбиране за методите на обучение, УИ "Св. Климент Охридски", ISBN 978-954-07-4355-4, София, 2018

[2] AA.VV. (1972). L'interdisciplinarité: problèmes d'enseignement et de recherche dans lesuniversités. Paris: Organisation de coopération et de développement économiques.

[3] DEVOTO-OLI (2009). Vocabolario della lingua italiana. Firenze: Le Monnier.

[4] Giorda, C. (2012). Così vicine, così lontane: storia e geografia di fronte a un percorso comune nei curricoli scolastici. Ambiente Società Territorio - Geografia nelle scuole, 2012 (2), pp. 1218.

[5] Perrig-Chiello, P., \& Darbellay, F. (eds.) (2002). Qu'est-ce que l'interdisciplinarité? : les nouveaux défis de l'enseignement. Lausanne: Réalités sociales.

[6] Ronza Flumiani, A. M., \& Ricchiuto, M. A. (1977). Geografia italiano e storia in un'esperienza di didattica interdisciplinare. Torino: Musolini.

[7] Scurati, C., \& Damiano, E. (1976). Interdisciplinarità e didattica. Brescia: La Scuola.

[8] Vasileva, M., A MORE COMPREHENSIVE UNDERSTANDING OF METHODS IN GEOGRAPHY TRAINING , KNOWLEDGE - INTERNATIONAL JOURNAL. SCIENTIFIC PAPERS VOL 19.1, редактор/и:Vlado Kambovski , издателство:GRAFOPROM - BITOLA, 2017, стр.:285-288

[9] Wasileva, M., Naydenov, K., Atanasov, D., CONTEMPORARY TRENDS IN GEOGRAPHICAL EDUCATION, InterCarto/InterGIS, редактор/и:Vladimir S. Tikunov , издателство:ELIBRARY.RU , 2017, стр.:205-210, doi:http://dx.doi.org/10.24057/2414-91792017-3-23-205-210, 